\title{
The hidden cost of health care
}

\section{Is biomedical research justified on moral and ethical grounds?}

\author{
What Price Better Health? Hazards \\ of the Research Imperative \\ by Daniel Callahan \\ University of California Press: 2003. 335 pp. \\ \$29.99, £19.95

\section{Arthur Caplan}

This book is intended for a wide general audience, but if you are a biomedical scientist, you would be well advised to read it. For the philosopher Daniel Callahan presents what might just be the strongest case for putting you out of business.

Callahan founded the Hastings Center, a bioethics research centre in New York state, and was its director for three decades. For much of that time he has wondered about the value of biomedical research. What Price Better Health? constitutes the crescendo of his dissatisfaction with the biomedical enterprise.

Biomedical research has set itself up inside an unassailable moral fortress, argues Callahan. Its main moral weapon is what he dubs the 'research imperative' — the idea that research must proceed regardless of the cost or risk. No downside can trump the research imperative, because a cure for all that ails us, and possibly a potion to stave off death itself, could be contained within the next grant proposal, embedded in the next biotech start-up, or just around the corner of the next widely touted new idea (be it fetal-tissue research, gene therapy, embryo research, xenografting, artificial organs, stem-cell research or genomics, for example). What hope is there for those who want to challenge the way that biomedical research is done, when to do so they must stand in the way of the research imperative, and thus in the path of progress?

In this book, Callahan attempts to slay the dragon of the research imperative with two main arguments. First, he says that the research imperative has completely corrupted biomedical science. Second, he argues that the research imperative is no imperative at all.

In chapter after chapter he argues that the price of biomedical science's drive to find cures for everything is corruption. The integrity of science in terms of honesty, openness and cooperation has completely frayed. The rights of humans in research are constantly being compromised or ignored. Conflicts of interest abound. Advocacy groups, regulatory bodies and government commissions simply roll over and play dead in the face of the promises of the research juggernaut. And lording over the whole unseemly mess, he says, is the bloated, greedy figure of the pharmaceutical industry, which earns huge profits while addicting us to drugs

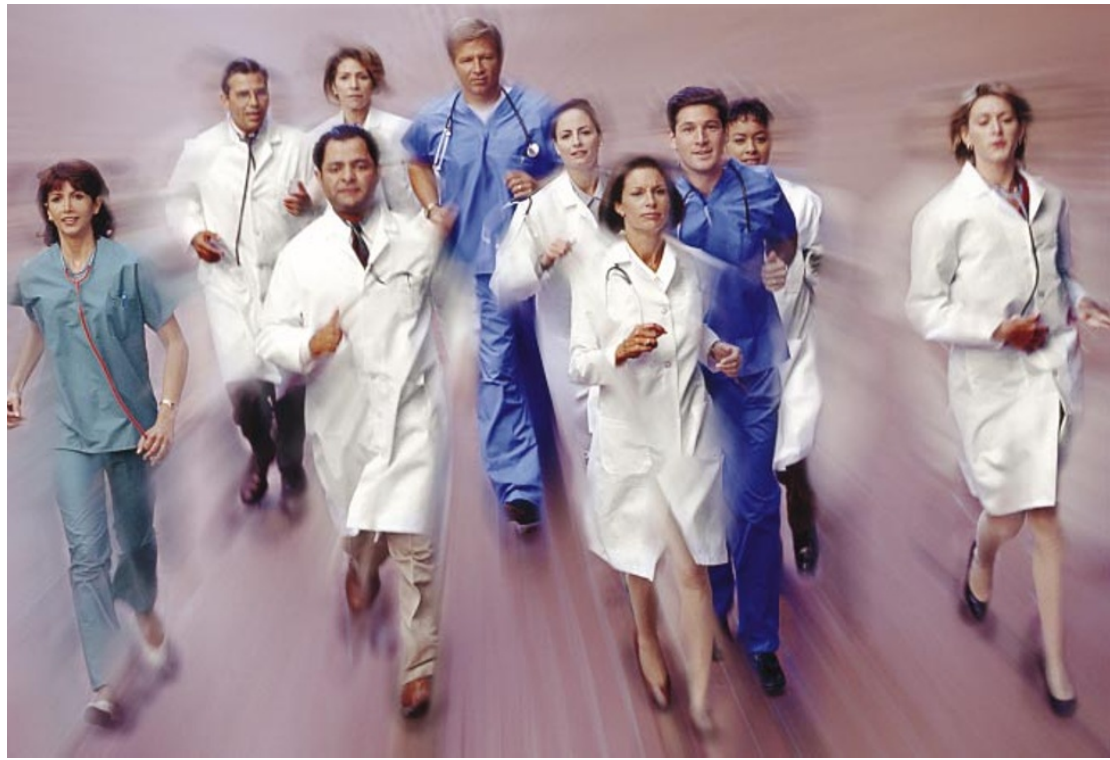

Dash for cash? But critics of biomedical research are seen as standing in the way of medical advances.

that don't work or that we don't really need.

Not only is the price exacted by obeisance to the research imperative far too high, but the imperative itself is a mirage. Callahan argues that there is no moral obligation to undertake biomedical research. First, he says that we have no duty to try and improve things for our descendants. Then he adds that although health is an important goal, it is far from being the only good that we have an obligation to produce.

So does he make his case? Should we try to shut down the US National Institutes of Health (NIH), INSERM (France's national biomedical agency), Britain's Medical Research Council and the pharmaceutical industry before they destroy us? Should we abandon the quest for eternal vigorous life and come to stoical grips with our finitude and frailty? Callahan displays a real mastery of policy and history but, despite his efforts, the research imperative does not yield to his rhetorical sword.

Is it really the case that the research imperative has a Svengali-like effect on all who hear its dulcet tones? Hardly. Even in the United States, whose government funding constitutes a good chunk of the world's share of biomedical research and development (R\&D), the total expenditure on biomedical research, even though it has grown over the past decade, is barely a detectable blip in the US economy.

Last year the US government spent more than $\$ 2$ trillion in total, of which $\$ 107$ billion went on R\&D. More than half of that amount went on military and defence-related research.
The NIH budget was roughly $\$ 27$ billion but a sizeable chunk of that was targeted at research on topics relating to bioterrorism and national security. Contrary to Callahan's view that Americans are digging deep into their wallets in egomaniacal hope of eternal life, their actual expenditure seems to show that they are well aware that there are lots of other things to spend money on, and they do.

What about the duty to make things better for those who will follow us? It is true that moral theories do not posit an obligation to improve the lot of those who have not yet been born. But we do have an obligation to try and make things better for our own children, and biomedical research is a crucial element of how that obligation should be discharged.

More to the point, we may also have a duty to support biomedical research because we choose to benefit from the fruits of past research. If I use a hearing aid, take insulin for my diabetes, walk using an artificial hip, wear a pacemaker, see through eyes shaped by laser surgery, and vaccinate myself against diseases, then I am benefiting from previous investments in biomedical research. It would seem that, unless I want to act as a 'free rider', I owe a debt to the investments of my forebears that must be discharged by continuing to support biomedical research. Fair play demands that I pay for what I benefit from.

If we do have a duty to do research, that brings us to the other part of Callahan's argument: has the biomedical research imperative crushed key values and core moral principles? Here Callahan's argument 
has some traction. Things are not as they should be in terms of internal values in biomedicine. Repairs are certainly in order.

Surprisingly, though, Callahan offers no comment on one of the most potent threats to scientific integrity and values - the power of government-sponsored military and antiterror research to undermine the integrity of science. This is not a new problem but recent events have raised its profile. In the United States and Europe, some of the greatest threats to key scientific values come from the desire of government to keep secret the work that it funds in the name of national security.

But having said that, do proponents of biomedical research really wield the researchimperative weapon in the way that Callahan maintains? Most biomedical researchers are keenly alert to the obligations to treat human and animal subjects respectfully and with dignity. They understand the tensions imposed by private funding on the ethos of their work. And they are open to listening to and taking seriously the objections of those who fret about where biomedical technology might take us. And so they should. Despite Callahan's hyperbole about the power of the biomedical research juggernaut, critics have scored some victories. The genetic modification of plants and animals is moving much more slowly than proponents would like; stem-cell, embryo and cloning research are being subjected to close scrutiny; and efforts to advance xenografting and the creation of artificial hearts have come more or less to a grinding halt for a variety of ethical and social reasons.

Callahan has written an important book. The research imperative may not be quite as invulnerable as he thinks, but it is certainly imperative that the case he makes against it be given the close and thoughtful attention that his book provokes.

Arthur Caplan is in the Department of

Medical Ethics, University of Pennsylvania

School of Medicine, Philadelphia,

Pennsylvania 19104-3308, USA.

.......................

Characters from the dawn of chemistry

The Last Sorcerers: The Path from Alchemy to the Periodic Table by Richard Morris

Joseph Henry Press: 2003. 296 pp. \$24.99

\section{John Emsley}

Who was the last true alchemist? Probably Johann Frederick Böttger (1682-1719), who started out looking for the Philosopher's Stone and ended up finding a way to make porcelain. Who was the first real chemist? Probably Robert Boyle (1627-91). He also began as an alchemist but became a chemist when he turned his attention to the newly discovered phosphorus in the 1670s. This he investigated in a systematic way, and he published his findings not in the arcane language of the alchemists, but in plain English.

This approach showed how far from alchemy Boyle had come, although he still believed that transmutation - turning one metal into another - might be achieved. For this reason, he fell prey to a scam wrought by a Frenchman, George Pierre des Clozets, who wrote to Boyle telling him that he could join a secret society of alchemists - for a fee. The upshot was that des Clozets milked Boyle of large sums of money. It is the inclusion of this kind of anecdote that makes Morris's book such a fascinating read.

The Last Sorcerers is a collection of short biographies of key individuals who span the years that saw the end of alchemy and the emergence of chemistry. It starts with an excellent account of Paracelsus and ends with one about Niels Bohr. Along the way we meet such chemistry greats as AntoineLurent Lavoisier, Henry Cavendish, Joseph Priestley, Jöns Jacob Berzelius and Dmitry Mendeleyev. In every case, Morris writes with a nice blend of science and human interest. I kept hoping that Morris might find a common thread of personality to unite his characters - what drove such a diverse bunch of men to study chemistry? Nothing illustrates the contrast more than the discoverers of hydrogen and oxygen. The former was the richest man in England; the latter was hounded out of the country for his radical left-wing views.

Cavendish was so wealthy that the Bank of England held his money in a special account. But he was so unworldly that when the bank sent a representative to suggest that he invest some of the $\mathfrak{E} 90,000$ (equivalent to about $£ 20$ million, or US $\$ 35$ million, today) that had accumulated in his account, he sent the man away saying he didn't want to be "plagued" about it, so there it sat growing ever larger. All Cavendish needed was enough money to enable him to carry out his experiments in his private laboratory in Clapham, and indeed he so little understood money that he gave the man whom he had employed to catalogue his library a cheque for $\mathfrak{E} 10,000$. Cavendish was a recluse and was terrified of women, yet he performed some remarkable experiments that changed the course of chemistry, most notably making, collecting and studying hydrogen gas.

Priestley did the same for oxygen, but he was a non-conformist preacher who was married and relatively poor. He wrote inflammatory pamphlets in support of the French and American revolutions, and was attacked not only by the press, but also by rioters in Birmingham, who burned down his house and laboratory.

Not all chemists were so badly treated; some were even admired and loved. When John Dalton died, aged 74, in Manchester in 1844 , the city fathers had his body taken to the Town Hall, where some 40,000 citizens filed past it to pay their last respects. The following day his funeral procession was a mile long, with 100 carriages and tens of thousands of ordinary people following on foot.

The Last Sorcerers is well-written popular science, and as such deserves to be widely read. That it deals with chemistry's somewhat shady origins adds to its attraction. The fact that it also reveals the human side of some famous chemists adds even more to one's enjoyment.

John Emsley is an author of popular chemistry books, his latest being Nature's Building Blocks (Oxford University Press).

\section{The bits that make up the Universe}

\section{Information: The New Language of Science}

by Hans Christian von Baeyer

Weidenfeld \& Nicolson: 2003. 258 pp. 116.99

Michael A. Nielsen

What is the Universe made of? A growing number of scientists suspect that information plays a fundamental role in answering this question. Some even go as far as to suggest that information-based concepts may eventually fuse with or replace traditional notions such as particles, fields and forces. The Universe may literally be made of information, they say, an idea neatly encapsulated in physicist John Wheeler's slogan: "It from bit". Others rather less boldly suggest that taking a point of view based on information theory may yield insights into existing theories such as statistical mechanics and quantum mechanics.

These are speculative ideas, still in the early days of development. Their most encouraging success is perhaps the resolution of the 'Maxwell's demon' paradox, a century-old riddle in the foundations of statistical mechanics. In James Clerk Maxwell's paradoxical thought experiment, a demon of extraordinary dexterity and visual acuity partitions an initially homogeneous gas into two parts, one part containing slowmoving molecules and the other part fastermoving ones. In the thought experiment, the gas is initially spread evenly through a two-chamber container with a connecting trapdoor that can be opened and closed by the demon. By carefully observing the velocity of molecules approaching the trapdoor, and opening or closing it as appropriate, the demon sorts the molecules so that fast molecules enter one chamber and slow ones end up in the other. 